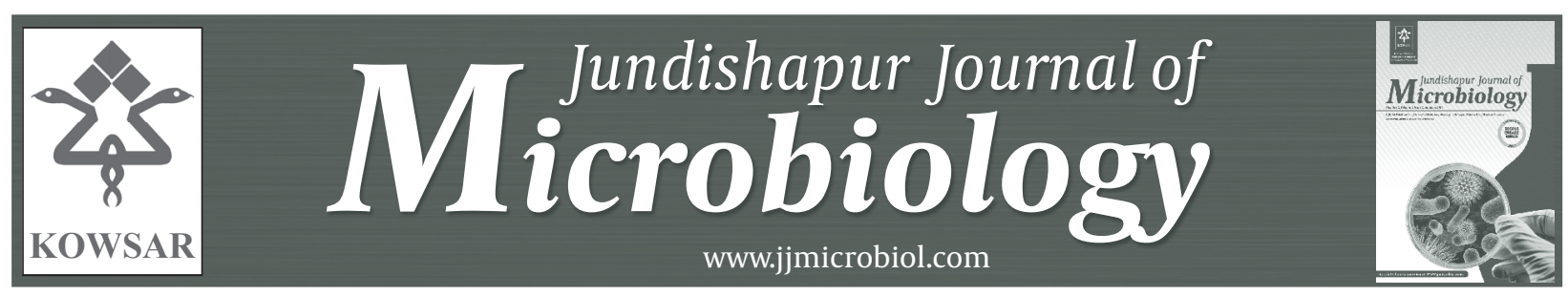

\title{
Cloning and Expression of Mycobacterium tuberculosis Major Secreted Pro- tein Antigen 85B (Ag85B) in Escherichia coli
}

\author{
Reza Zarif ${ }^{1^{*}}$, Mojtaba Sankian ${ }^{2}$, Aida Gholubi ${ }^{1}$, Zahra Farshadzadeh ${ }^{1}$, Saman Soleiman- \\ pour ${ }^{1}$, Forough Youssefi ${ }^{1}$, Mehrangiz Khaje Karamoddini ${ }^{1}$, Kiarash Ghazvini ${ }^{1}$, Abdol Reza \\ Varasteh $^{2}$ \\ ${ }^{1}$ Microbiology \& Virology Research Center, Bu-Ali Research Institute, Mashhad University of Medical Sciences, Mashhad, IR Iran \\ ${ }^{2}$ Division of Immunobiochemistry, Immunology Research Center, Bu-Ali Research Institute, Mashhad University of Medical Sciences, Mashhad, IR Iran \\ * Corresponding author: Reza Zarif, Microbiology and Virology Research Center, Bu-Ali Research Institute, Mashhad University of Medical Sciences, Mash- \\ had, IR Iran.Tel.: +98-5117262776 , Fax: +98-5117262776, E-mail: zarif.r@gmail.com
}

\section{A B S T R A C T}

Background: The $30 \mathrm{kDa}$ major secretory protein of Mycobacterium tuberculosis (antigen 85B) is a primary vaccine candidate. This secreted antigen induces a protective immune response and stimulates the production of IFN- $\gamma$ in animal models.

Objectives: The aim of this study was cloning and expression of Ag 85B of M. tuberculosis in Escherichia coli.

Materials and Methods: To produce recombinant Ag85B, the fbpB gene was amplified by PCR method. Then inserted into the pET101/D vector and transported into E. coli strain TOPO10. Plasmid containing pET101/D: Ag85B was transformed into competence E.coli BL21(DE3). The transformed E.coli strain BL21 was effectively expressed recombinant Ag85B.

Results: The expressed fusion protein was found almost entirely in the insoluble form. Followed by sonication to disrupt the cells, Solution of the cell debris was centrifuged and after use of Ni-NTA column and 6 molar urea and $6 \mathrm{M}$ guanidine-HCl solutions recombinant protein was purified.

Conclusions: These results could serve as a basis for further studies in endemic regions of tuberculosis on the usefulness of this gene and its expression product in the development of subunit vaccine and DNA vaccine against tuberculosis.

Keywords: Antigen 85B; Mycobacterium tuberculosis; Cloning; Organism

Copyright (C) 2013, Kowsar Corp.; Published by Kowsar Corp.

Article type: Research Article; Received: 04 Mar 2012, Revised: 22 May 2012, Accepted: 07 Jun 2012; DOI: 10.5812/jjm.4701

-Implication for health policy/practice/research/medical education:

Results of current study could serve to develop diagnostic methods and subunit vaccine production against tuberculosis.

Please cite this paper as:

Zarif R, Sankian M, Gholubi A, Farshadzadeh Z, Soleimanpour S, Youssefi F, khajeh Karamoddini M, Ghazvini K and Varasteh AR. Cloning and Expression of Mycobacterium tuberculosis Major Secreted Protein Antigen 85B (Ag85B) in Escherichia coli. Jundishapur J Microbiol. 2013;6(2):112-116.DOI: 10.5812/jjm.4701

Copyright ( 2013 Ahvaz Jundishapur University of Medical Sciences; Published by Kowsar Corp.

This is an Open Access article distributed under the terms of the Creative Commons Attribution License(http://creativecommons.org/licenses/by/3.0), which permits unrestricted use, distribution, and reproduction in any medium, provided the original work is properly cited. 


\section{Background}

Mycobacterium tuberculosis, the major agent of tuberculosis, is responsible for two million deaths annually worldwide, making it as the world's most common cause of death from a particular single infectious agent (1). Appearance of new strains of M. tuberculosis resistant to the conventional antibiotics has raised concern for seeking better vaccines and drugs against this pathogen (2).M. tuberculosis expresses three closely correlated mycolyl tranferases, also recognized as the Antigen 85 Complex (ag85A, ag85C are $32 \mathrm{kDa}$ and ag85B is $30 \mathrm{kDa}$ ). The antigen 85 (Ag85) complex is a family of fibronectin-binding proteins which are considered to be potential virulence factors. These proteins encoded by the genes $f b p A, f b p B$, and $f b p C$, respectively. These genes show no resemblance in their $5^{-}$upstream region, and they are probably regulated independently at the transcriptional level. it was proved that M. tuberculosis binds specifically to fibronectin than any other purified extracellular matrix proteins like collagen and fibrinogen (3). These three proteins play roles in cell wall synthesis by catalyzing transport of mycolic acid from one trehalose 6-monomycolate to another, resulting in trehalose6, $6^{\prime}$-dimycolate and free trehalose (4).

The members of antigen 85 family are expressed at a sTable-state ratio of 3:2:1 (ag85B:ag85A:ag85C), while the three genes are unlinked. The $30 \mathrm{kDa}$ antigen $85 \mathrm{~B}$ is the most plentiful of the three, and is the most copious extracellular protein of $M$. tuberculosis, responsible for almost $25 \%$ of the total extracellular protein in broth culture (5). In M. tuberculosis phagosomes within human macrophages, the antigen $85 \mathrm{~B}$ molecules are found in high level in the phagosomal space and on the bacterial cell wall (5). The $30 \mathrm{kDa}$ major secretory protein of $M$. tuberculosis (antigen 85B) is an important vaccine candidate. Vaccination of guinea pigs with the purified $M$. tuberculosis ag85B induced significant protective immunity against aerosol exposure to $M$. tuberculosis bacteria (6).In addition it was shown in guinea pigs BCG vaccine that over expression of the Ag85B component induces stronger protective immunity against aerosol challenge than conventional M. bovis BCG vaccine (7).

This recombinant BCG vaccine is the first vaccine confirmed to be more potent than conventional BCG vaccine since the recombinant vaccine was developed. Indeed, vaccination of $\mathrm{C} 57 \mathrm{BL} / 6$ mice with naked plasmid DNA encoding Ag85B could arouse strong humoral and cell-mediated immune responses and gave considerable protection against aerosol or intravenous exposure to live M. tuberculosis $\mathrm{H} 37 \mathrm{Rv}(8)$. So far, murine Th1 T-cell epitopes have been explained for Ag85B (9).

\section{Objectives}

The purpose of this study was to clone, identify and express the major secreted protein antigen 85B from $M$. tuberculosis and to arrange a good foundation for the diagnosis of $M$. tuberculosis, for developing new subunit vaccine.

\section{Materials and Methods}

\subsection{Mycobacteria}

M. tuberculosis H37Rv (ATCC 27294) was obtained from the Pasteur Institute of Iran and maintained on Lowenstein Jensen's (LJ) medium in the laboratory, to extract the mycobacterial DNA. The bacteria were treated with lysozyme and proteinase K(Sigma, USA), lysed with sodium dodecyl sulfate, phenol extracted, and precipitated with ethanol (Merck, Germany).

\subsection{PCR Cloning}

The gene encoding antigen 85B amplified by PCR technique with forward (5' CACCATGACAGACGTGAGCCGAAAGATTC $3^{\prime}$ ) and reverse (5' GCC GGC GCC TAA CGA ACT CT $3^{\prime}$ ) primers. The $20 \mu \mathrm{L}$ PCR mixture contained 2 $\mu \mathrm{L}$ 10X Pfu buffer, $4.8 \mu \mathrm{l} \mathrm{Mg} 2 \mathrm{SO} 4,1.6 \mu \mathrm{L}$ dNTP, $1 \mu \mathrm{L}$ Ag85BF primer (10 pmol), $1 \mu \mathrm{L}$ Ag85B-R primer(10 pmol), $3 \mu \mathrm{L}$ genomic DNA, $1.25 \mu \mathrm{L}$ of $5 \mathrm{U} / \mu \mathrm{L}$ Pfu DNA polymerase (Fermentas, USA) and $5.35 \mu \mathrm{L}$ water. PCR amplification involved the initial denaturation at $95^{\circ} \mathrm{C}$ for $5 \mathrm{~min}$, followed by 35 cycles each consisting of a $45 \mathrm{~s}$ denaturation at $95^{\circ} \mathrm{C}$, a $60 \mathrm{~s}$ annealing at $57^{\circ} \mathrm{C}$, and a 2.5 min extension at $72^{\circ} \mathrm{C}$. The final extension following the 35 cycles was allowed for $10 \mathrm{~min}$ at $72{ }^{\circ} \mathrm{C}$.

The amplified PCR product, electrophoresed and eluted from agarose gel, was ligated into pET101/D-TOPO, which allowed translational fusion between a C-terminal six-His tag and a target gene (Invitrogen, USA), and was transformed into Escherichia coli strain TOPO 10. So as to isolate plasmids from correct colons we applied QIAprep spin miniprep kit (Qiagen, Germany). Positive clones were selected by colony PCR, and confirmed by digestion with sac restriction enzyme (Fermentas, USA). Afterward the recombinant plasmids purified from positive clones were ready for nucleotide sequencing. Plasmid containing pET101/D Ag85B was transformed into competence E. coli BL21 (DE3).

\subsection{Production of Recombinant Ag85B}

E.coli strain BL21 transformed with pET101/D Ag85B was placed on LB solid medium containing ampicillin (100 $\mu \mathrm{g} / \mathrm{mL}$ ) (Merck, Germany), and grown overnight at 37 ${ }^{\circ} \mathrm{C}$. An overnight culture was made to inoculate $200 \mathrm{ml}$ LB with ampicillin medium. After growing to an optical density of 0.5 at $600 \mathrm{~nm}$ at $37{ }^{\circ} \mathrm{C}$, the production of Ag85B protein was induced by adding isopropyl- $\beta$-D thiogalactopyranoside (IPTG) (Sigma, USA) to a final 
concentration of $2 \mu \mathrm{L} / \mathrm{mL}$.

\subsection{Purification and Folding of Recombinant Ag85B}

Cell pellet was centrifuged and suspended in $20 \mathrm{ml}$ of lysis buffer $(300 \mathrm{mM} \mathrm{NaCl}, 50 \mathrm{mM}$ Tris_/HCl, pH 7.6, $100 \mathrm{mMKcl}, \% 10$ glycerol, \%0.5 Tryton X100, 6M guanidine) followed by sonication at $4^{\circ} \mathrm{C}$ to disrupt the cells. Solution of the cell debris was incubated on $37^{\circ} \mathrm{C}$ for $15 \mathrm{~min}$. Afterward cell pellet was frozen in liquid nitrogen and thawed in $37^{\circ} \mathrm{C}$ and centrifuged in $10^{\circ} \mathrm{C}$. After washing the $5 \mathrm{ml}$ column of Ni-NTA resin (Qiagen, Germany) with $5 \mathrm{ml}$ of buffer contained (6M guanidine_/HCl, $50 \mathrm{mM}$ sodium acetate, $8 \mathrm{mM}$ 2-mercaptoethanol, pH 6.5) the supernatant passed through the column. Next the column was washed with $15 \mathrm{ml}$ of the same buffer followed by buffers containing $6 \mathrm{M}$ guanidine- $\mathrm{HCl}, 50 \mathrm{mM}$ sodium acetate, $\mathrm{pH}$ 5.9. Finally rec. Ag85B was eluted with $15 \mathrm{ml}$ of elution solution (4.5 M urea, $50 \mathrm{mM}$ sodium acetate, $\mathrm{pH}$ 4.5). Refolding of the denatured rec.Ag85B was fulfilled by serial dialysis at $4^{\circ} \mathrm{C}$ in the following buffers for overnight: 40 mM Tris_/ $\mathrm{HCl}, 0.1 \mathrm{mM}$ 2- mercaptoethanol, 0.1\% mannitol and $2 \mathrm{M}$ urea, $\mathrm{pH} 11$, then by the same buffer with $1 \mathrm{M}$ urea, and then without urea; (buffer of $40 \mathrm{mM}$ Tris_/HCl, 0.1 mM 2- mercaptoethanol, 0.1\% mannitol, pH 8.8); buffer of $40 \mathrm{mM}$ Tris_/HCl, pH 8.8; and finally buffer of $10 \mathrm{mM} \mathrm{KH} 2 \mathrm{PO} 4, \mathrm{pH} 8.5$.

\section{Results}

In this study, we amplified antigen 85B from M. tuberculosis genomic DNA with PCR. The PCR product was confirmed to be a 978 bp DNA segment using agarose gel electrophoresis, as expected (Figure 1).

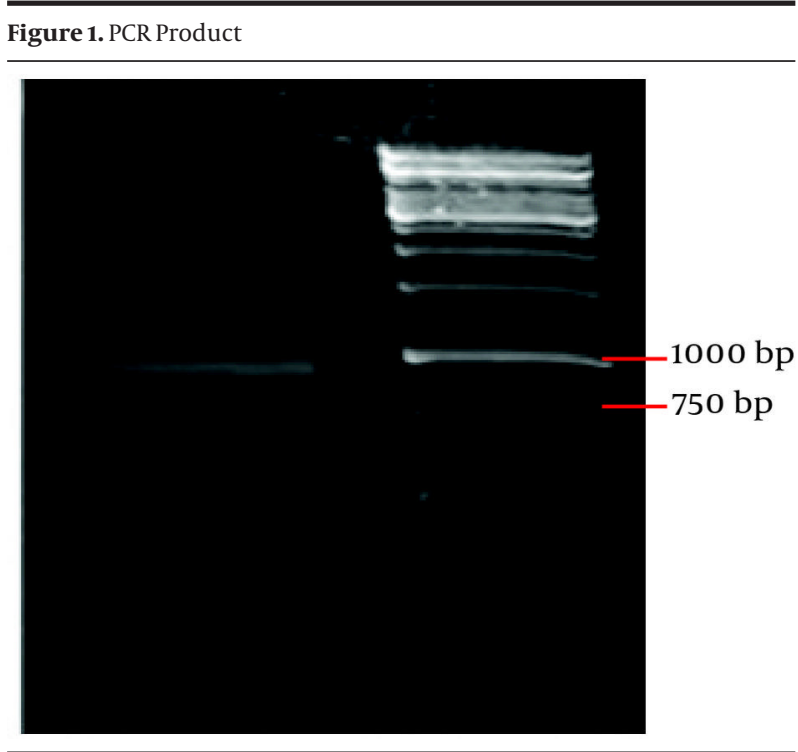

Lane 1: band of 978 bp. Lane2:1 kbp DNA marker (Fermentas)

\subsection{Analysis of Recombinant Clones}

sacI restriction analysis of these three purified recombinant clones DNA (Figure 2) revealed the same types of insertion. All clone had an insertion with a total length of about 1 kilobases $(\mathrm{kb})$ with no additional internal sacI sites. The empty plasmid has 5753 nucleotide length with 1 cut site for sacI at nucleotide 317 (10). So we expected to observe a band about 7000 bp on agarose gel.

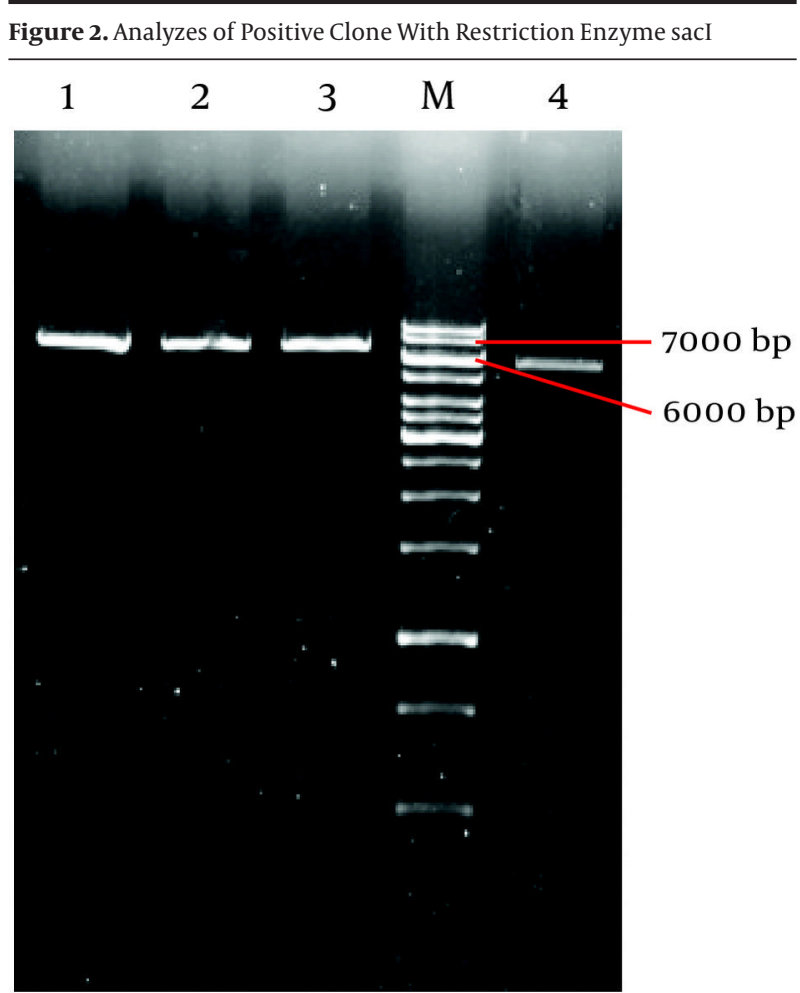

Line 1, 2, 3: Recombinant plasmid digest by sacI restriction enzyme. Line4:empty plasmid digests by sacI. M:1kbp ladder

Plasmid sequencing was performed to confirm DNA encoding Ag85B is inserted in the correct frame. Plasmid sequencing was performed by Seq Lab (Germany). Alignment of sequence showed that recombinant DNA was \%100 homologous with M. tuberculosis secreted antigen Ag85B gene, complete cds (AY207396.1). The recombinant plasmid was transformed to expression host E. coli strain BL21. After IPTG induction for $12 \mathrm{~h}$, the recombinant Ag85B was abundant in the total lysates. Antigen 85B was expressed at about $33 \mathrm{kDa}$ on SDS-PAGE and wholly was found in the inclusion body (Figure 3)

With the aim of refold recombinant protein we used a quasi-static-like process (11). In this method the inclusion body was lysed in solution contain $6 \mathrm{M}$ guanidineHCl. Passes trough Ni-NTA column and purified using 5 step dialyses. Subsequently rec. protein was displayed using silver staining method as expected (Figure 4). The amino acid sequencing was performed by Seq Lab (Ger- 
many) to ensure correct orientation and reading frame of the expressed rec. protein.

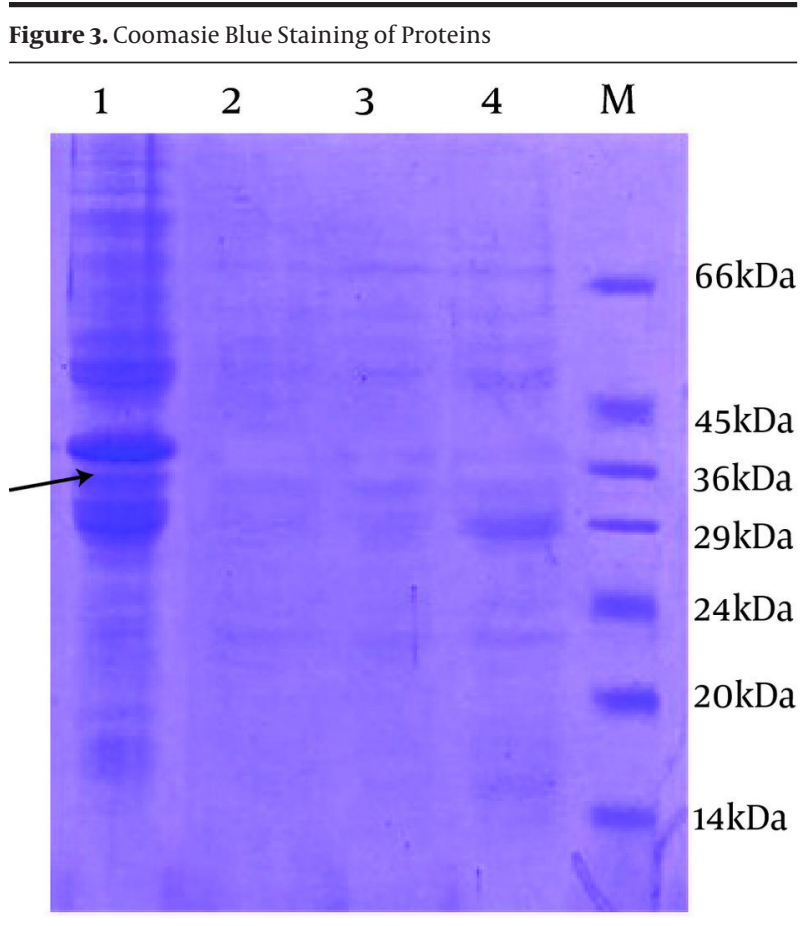

Line 1: fractions of inclusion body, rec.Ag85B are shown by arrow. Line 2, 3, and 4: are soluble phase of 3 different clone. Lane M: The Protein size marker

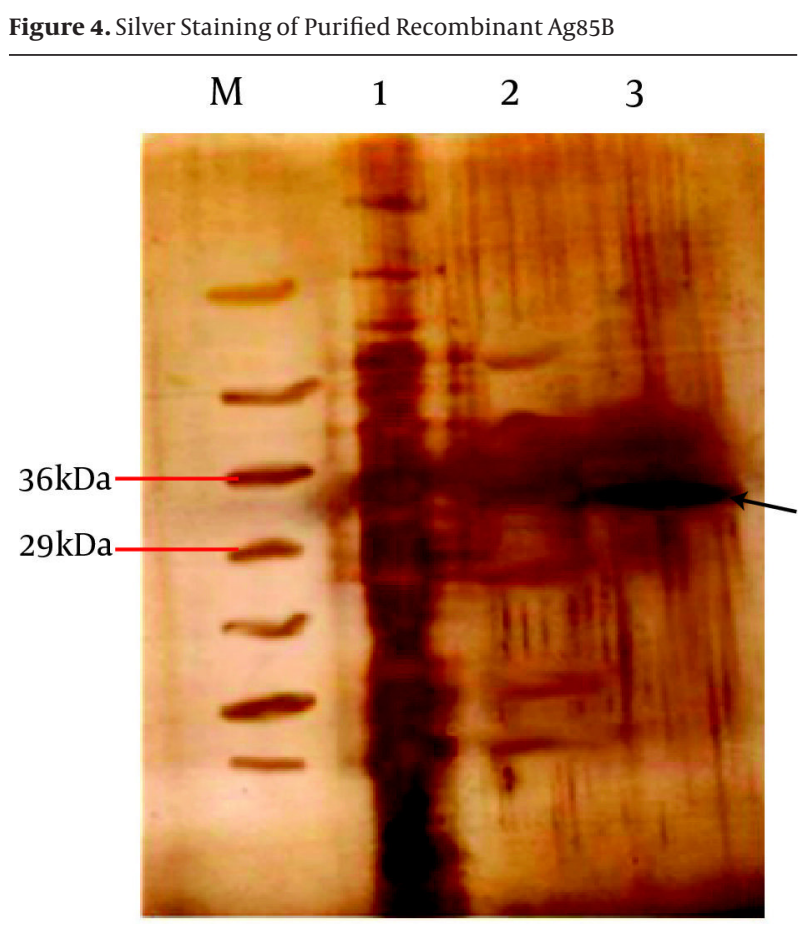

Line 1: Sediment. Line 2: before dialyses. Line 3: after dialyses (purified). Recombinant Ag85B is shown by arrow. Lane M: The Protein size marker

\section{Discussion}

For many years, great efforts have been made to develop new vaccines against tuberculosis and to design better methods for the diagnosis of the disease. Expressing the antigen $85 \mathrm{~B}$ protein could serve as an important basis for further studies on the usefulness of this gene and its expression product in the development of subunit vaccine and diagnostic methods. In this view, the $30 \mathrm{kDa}$ major extracellular protein of $M$. tuberculosis is of great importance. The potential immunoprotective value of the $30 \mathrm{kDa}$ protein has been recognized in the closely pertinent guinea pig model of pulmonary tuberculosis (6).

There are several reports describing the cloning and expression of the CFP-10 gene in different expression vectors such as pUC18 (12), pRSETB (13), pGEMt-Easy vector, pVAX1(14), pMCT6 (15) and pET17b (16). In a series of studies Lakey et al., reported cloning and expression of Ag85A and Ag85B. For the expression of recombinant protein, they used $p$ TrcHisB vector and E. coli TOP10 expression host. Their study claims that $p \operatorname{Tr} c H i s B$ vector overcomes the problem of low $\mathrm{G}+\mathrm{C}$ percentage in $\mathrm{E}$. coli genome. They purified recombinant proteins under denaturing conditions and urea removal was not performed (17).

Kremer and colleagues cloned Ag85A, Ag85B and Ag85C and evaluated their mycolyl transferase activity. For gene expression they used pET23b (+) vector which contains T7 promoter and E. coli C41 (DE3) host but they failed to produce recombinant Ag85B to a considerable amount, so that they preferred to use the native Ag85B (18). Fukui and Yoneda explained the purification of this antigen from M. tuberculosis H37Rv culture fluid (19). Kuzuhiro Matsuo et al,. Cloned and sequenced MPT59 gene of $M$. bovis BCG in 1988. They used the Plasmid vector pUC18 and expressed the protein using pKK233-2 expression vector. To clone this gene, they digested plasmid vector and performed insertion with restriction enzyme Kpn (12). Similarly, other researchers used this technique (double cut) to clone this gene $(13,15,16)$.

In this regard we applied directional cloning method to insert the blunt end PCR product to expression vector. We had no need to cut insertion gene or plasmid to ligation. In this study similar to other researches that were performed by other researchers, antigen $85 \mathrm{~B}$ was expressed and found entirely in the inclusion body $(13,15)$. Expression of recombinant protein with the Cterminal Fusion Tag increased the size of recombinant protein $3 \mathrm{kDa}$ in the SDS-page. The presence of the Cterminal polyhistidine (6xHis) tag allows purification of recombinant fusion protein with a metal-chelating resin (Ni-NTA) (20).

In conclusion, with the increasing number of people infected and killed with M. tuberculosis, investigations focusing on the development of new therapeutics remains of extreme importance and necessity. The re- 
search presented here could help and assist the study of anti-tubercular therapeutics and vaccine design in endemic regions.

\section{Acknowledgements}

This work was supported by departments of Immunobiochemistry and Microbiology of Bu-Ali Research Institute of Mashhad.

\section{Financial Disclosure}

The authors report no conflicts of interest. The authors alone are responsible for the content and writing of the paper.

\section{Funding/Support}

This study was financially supported by Mashhad University of Medical Sciences, Mashhad, Iran.

\section{Authors' Contribution}

None declared.

\section{References}

1. Dye C, Scheele S, Dolin P, Pathania V, Raviglione MC. Consensus statement. Global burden of tuberculosis: estimated incidence, prevalence, and mortality by country. WHO Global Surveillance and Monitoring Project. JAMA. 1999;282(7):677-86.

2. Grosset J. Current problems with tuberculosis treatment. Res Microbiol. 1996;147(1-2):10-6.

3. Ratliff TL, McGarr JA, Abou-Zeid C, Rook GA, Stanford JL, Aslanzadeh J, et al. Attachment of mycobacteria to fibronectin-coated surfaces. J Gen Microbiol.1988;134(5):1307-13.

4. Belisle JT, Vissa VD, Sievert T, Takayama K, Brennan , Besra GS. Role of the major antigen of Mycobacterium tuberculosis in cell wall biogenesis. Science. 1997;276(5317):1420-2.

5. Harth G, Lee BY, Wang J, Clemens DL, Horwitz MA. Novel insights into the genetics, biochemistry, and immunocytochemistry of the 30-kilodalton major extracellular protein of Mycobacterium tuberculosis. Infect Immun. 1996;64(8):3038-47.

6. Horwitz MA, Lee BW, Dillon BJ, Harth G. Protective immunity against tuberculosis induced by vaccination with major extracellular proteins of Mycobacterium tuberculosis. Proc Natl Acad Sci USA. 1995;92(5):1530-4.

7. Horwitz MA, Harth G, Dillon BJ, Maslesa-Galic S. Recombinant bacillus calmette-guerin (BCG) vaccines expressing the Mycobacterium tuberculosis 30-kDa major secretory protein induce greater protective immunity against tuberculosis than conventional BCG vaccines in a highly susceptible animal model. Proc Natl Acad Sci USA. 2000;97(25):13853-8.

8. Kamath AT, Feng CG, Macdonald M, Briscoe H, Britton WJ. Dif ferential protective efficacy of DNA vaccines expressing secreted proteins of Mycobacterium tuberculosis. Infect Immun. 1999;67(4):1702-7.

9. Yanagisawa S, Koike M, Kariyone A, Nagai S, Takatsu K. Mapping of VB11+ helper T-cell epitopes on mycobacterial antigen in mouse primed with Mycobacterium tuberculosis. Int Immunol. 1997;9:227-37.

10. Chen A. Invitrogen ${ }^{\mathrm{TM}}$ life technologies, DNA pet101d_topo_verA Restriction Map. 2002

11. Chang CC, Su YC, Cheng MS, Kan LS. Protein folding by a quasistatic-like process: a first-order state transition. Phys Rev E Stat Nonlin Soft Matter Phys. 2002;66(2 Pt 1):21903.

12. Matsuo K, Yamaguchi R, Yamazaki A, TasakaH, Yamada T. Cloning and expression of the Mycobacterium bovis BCG gene for extracellular alpha antigen.J Bacteriol.1988;170(9):3847-54.

13. Russo DM, Kozlova N, Lakey DL, Kernodle D. Naive human T cells develop into Th1 effectors after stimulation with Mycobacterium tuberculosis-infected macrophages or recombinant Ag85 proteins. Infect Immun. 2000;68(12):6826-32.

14. Grover A, Ahmed MF, Singh B, Verma I, Sharma P, Khuller GK A multivalent combination of experimental antituberculosis DNA vaccines based on Ag85B and regions of difference antigens. Microbes Infect. 2006;8(9-10):2390-9.

15. Weinrich Olsen A, van Pinxteren LA, Meng Okkels L, Birk Rasmussen P, Andersen P. Protection of mice with a tuberculosis subunit vaccine based on a fusion protein of antigen $85 \mathrm{~b}$ and esat-6. Infect Immun. 2001;69(5):2773-8.

16. Al-Attiyah R, Mustafa AS, Abal AT, El-Shamy AS, Dalemans W, Skeiky YA. In vitro cellular immune responses to complex and newly defined recombinant antigens of Mycobacterium tuberculosis. Clin Exp Immunol. 2004;138(1):139-44.

17. Lakey DL, Voladri RK, Edwards KM, Hager C, Samten B, Wallis RS, et al. Enhanced production of recombinant Mycobacterium tuberculosis antigens in Escherichia coli by replacement of lowusage codons. Infect Immun. 2000;68(1):233-8.

18. Kremer L, Maughan WN, Wilson RA, Dover LG, Besra GS. The M. tuberculosis antigen 85 complex and mycolyltransferase activity. Lett Appl Microbiol. 2002;34(4):233-7.

19. Yoneda M, Fukui Y, Yamanouchi T. Extracellular proteins of tubercle bacilli. V. Distribution of alpha and beta antigens in various mycobacteria. Biken J. 1965;8(4):201-23.

20. InvitrogenTM. Champion pET directional TOPO $®$ expression kits Five-minute, directional TOPO $®$ Cloning of blunt-end PCR products into vectors for high-level, inducible expression in E. In: K100-01 , K102-01, K151-01, K200-01, . coli Catalog nos. U.S.A: Version $\mathrm{H} ; 2006$ 